\title{
Cytotoxic Xanthones from Garcinia penangiana Pierre
}

Md. Lip Jabit ${ }^{a}$, Rozida Khalid ${ }^{a}$, Faridah Abas ${ }^{\mathrm{a}, \mathrm{b}}$, Khozirah Shaaria,c, Lim Siang Hui ${ }^{\mathrm{d}}$, Johnson Stanslas ${ }^{\mathrm{a}, \mathrm{d}}$, and Nordin H. Lajis ${ }^{\mathrm{a}, \mathrm{c}, *}$

a Laboratory of Natural Products, Institute of Bioscience, University Putra Malaysia, 43400 Serdang, Selangor, Malaysia. Fax: +603894680 80. E-mail: nhlajis@ibs.upm.edu.my

b Department of Food Science, Faculty of Food Science and Technology, University Putra Malaysia, 43400 Serdang, Selangor, Malaysia

c Department of Chemistry, Faculty of Science, University Putra Malaysia, 43400 Serdang, Selangor, Malaysia

d Faculty of Medicine and Health Sciences, University Putra Malaysia, 43400 Serdang, Selangor, Malaysia

* Author for correspondence and reprint requests

Z. Naturforsch. 62 c, 786-792 (2007); received April 17/May 25, 2007

Two new xanthones, characterized as 4-(1,1-dimethylprop-2-enyl)-1,3,5,8-tetrahydroxyxanthone (1) and penangianaxanthone (2), with three known xanthones, cudratricusxanthone $\mathrm{H}$ (3), macluraxanthone $C(4)$ and gerontoxanthone $C(5)$, as well as friedelin and stigmasterol were isolated from the leaves of Garcinia penangiana. Their structures were elucidated by analysis of spectroscopic data and comparison of the NMR data with the literature ones. Significant cytotoxicity against DU-145, MCF-7 and NCI-H460 cancer cell lines was demonstrated by compounds $\mathbf{1}-\mathbf{5}$, with $\mathrm{IC}_{50}$ values ranging from 3.5 to $72.8 \mu \mathrm{M}$.

Key words: Garcinia penangiana, Cytotoxic Activity, Xanthones

\section{Introduction}

The medicinal properties of the species Garcinia (family Guttiferae) are well documented, both on their traditional use as well as the scientific basis for their biological activities (Burkill, 1966; Cao et al., 1998; Chomnawang et al., 2005; Grosvenor et al., 1995; Tona et al., 1999). Isolation of xanthones, benzophenones, triterpenes and biflavonoids has been reported (Ali et al., 2000; Matsumoto et al., 2003a; Peres et al., 2000; Waterman and Hussain, 1983). The constituents isolated from Garcinia exhibit various bioactivities, such as antitumour, anti-inflammatory (Lin et al., 1997; Nakatani et al., 2002) and antibacterial (Permana et al., 2001; Rukachaisirikul et al., 2003). Xanthones are especially noted as potential antitumour and chemopreventive agents (Chiang et al., 2003; Ito et al., 2003; Mackeen et al., 2000; Matsumoto et al., 2003b; Thoison et al., 2000). In this report, the isolation of two new cytotoxic prenylated xanthones, 4-(1,1-dimethylprop-2-enyl)-1,3,5,8-tetrahydroxyxanthone (1) and the furanoxanthone penangianaxanthone (2), is described. Three known xanthones, including cudratricusxanthone $\mathrm{H}(\mathbf{3})$, macluraxanthone C (4) and gerontoxanthone C (5), along with friedelin and stigmasterol were also isolated.

\section{Results and Discussion}

Compound $\mathbf{1}$ was isolated as a yellow amorphous solid with a melting point of $220-222^{\circ} \mathrm{C}$. The EIMS spectrum exhibited the HREIMS molecular ion peak $\left(\left[\mathrm{M}^{+}\right]\right)$at $\mathrm{m} / z \quad 328.3269$ corresponding to the molecular formula $\mathrm{C}_{18} \mathrm{H}_{16} \mathrm{O}_{6}$. The UV spectrum showed typical absorptions of the xanthone chromophore at 226, 256, 281 and $325 \mathrm{~nm}$ (Govindachari et al., 1971). The absorption bands at $3392,2922,1585$, and $1031 \mathrm{~cm}^{-1}$ in the IR spectrum indicated the presence of hydroxy, alkyl, carbonyl, and allyl groups, respectively.

The ${ }^{1} \mathrm{H}$ NMR spectrum contained nine signals representing two chelated hydroxy groups $\left[\delta_{\mathrm{H}}\right.$ $12.26,1 \mathrm{H}(\mathrm{s})$ and $\left.\delta_{\mathrm{H}} 11.18,1 \mathrm{H}(\mathrm{s})\right]$, two orthocoupled protons $\left(\delta_{\mathrm{H}} 7.32, \mathrm{~d}, J=9.0 \mathrm{~Hz}, \mathrm{H}-6\right.$ and $\left.\delta_{\mathrm{H}} 6.64, \mathrm{~d}, J=9.0 \mathrm{~Hz}, \mathrm{H}-7\right)$, a set of four signals of the 1,1-dimethylallyl group $\left[\delta_{\mathrm{H}} 6.58(\mathrm{dd}, J=\right.$ $\left.17.0,10.0 \mathrm{~Hz}, \mathrm{H}-2^{\prime}\right), \delta_{\mathrm{H}} 5.11(\mathrm{dd}, J=17.0,1.5 \mathrm{~Hz}$, $\left.\mathrm{H}_{\text {trans }}-3^{\prime}\right), \delta_{\mathrm{H}} 4.95\left(\mathrm{dd}, J=10.0,1.5 \mathrm{~Hz}, \mathrm{H}_{\text {cis }}-^{\prime}\right)$ and $\delta_{\mathrm{H}} 1.76\left(2 \mathrm{CH}_{3}, \mathrm{~s}, \mathrm{H}-4^{\prime}\right.$ and $\left.\left.\mathrm{H}-5^{\prime}\right)\right]$, and one aromatic proton $\left(\delta_{\mathrm{H}} 6.38, \mathrm{~s}, \mathrm{H}-2\right)$.

The ${ }^{13} \mathrm{C}$ NMR spectrum revealed the presence of 18 carbon atoms including one carbonyl carbon atom by a signal at $\delta_{\mathrm{C}} 185.2$ (C-9). Further inspection on the ${ }^{13} \mathrm{C}$ NMR and HSQC spectra indicated 
the presence of two aromatic rings with six oxygenated carbon atoms, corresponding to a tetrahydroxylated xanthone and one dimethylallyl group. In the HMBC spectrum, correlations were observed between the dimethyl signals $\left(\delta_{\mathrm{H}} 1.76\right.$, $\left.\mathrm{CH}_{3}-4^{\prime} / \mathrm{CH}_{3}-5^{\prime}\right)$ with the carbon signal of $\mathrm{C}-4\left(\delta_{\mathrm{C}}\right.$ 112.5), thus allowing us to assign the connectivity of a dimethylallyl moiety at C-4.

The assignment of a hydroxy group at $\mathrm{C}-1$ was based on the HMBC correlation of the chelated hydroxy signal at $\delta_{\mathrm{H}} 12.26$ with the carbon signals at $\delta_{\mathrm{C}} 161.3(\mathrm{C}-1), \delta_{\mathrm{C}} 99.8(\mathrm{C}-2)$ and $\delta_{\mathrm{C}} 102.2(\mathrm{C}-$ 9a). The correlation of the proton signal at $\delta_{\mathrm{H}} 6.38$ with the carbon signals at $\delta_{\mathrm{C}} 161.3(\mathrm{C}-1), \delta_{\mathrm{C}} 165.5$ $(\mathrm{C}-3), \delta_{\mathrm{C}} 112.5$ (C-4) and $\delta_{\mathrm{C}} 102.2$ (C-9a) confirmed the assignment of an aromatic methine carbon atom of C-2. The chelated hydroxy group at $\delta_{\mathrm{H}} 11.18$ correlated with the carbon signals at $\delta_{\mathrm{C}}$ $153.1(\mathrm{C}-8), \delta_{\mathrm{C}} 107.4(\mathrm{C}-8 \mathrm{a})$ and $\delta_{\mathrm{C}} 109.3(\mathrm{C}-7)$ in the $\mathrm{HMBC}$ spectrum, thus suggesting that the $\mathrm{OH}$ group was located at C-8. The assignment of the ortho-coupled H-6 proton $\left(\delta_{\mathrm{H}} 7.32\right)$ was based on its correlations with the carbon signals at $\delta_{\mathrm{C}} 153.1$ $(\mathrm{C}-8), \quad \delta_{\mathrm{C}} 137.6$ (C-5) and $\delta_{\mathrm{C}} 144.0$ (C-10a), whereas, the assignment of the $\mathrm{H}-7$ proton $\left(\delta_{\mathrm{H}}\right.$ 6.64) was based on its correlations with the signals at $\delta_{\mathrm{C}} 153.1(\mathrm{C}-8), \delta_{\mathrm{C}} 107.4(\mathrm{C}-8 \mathrm{a})$ and $\delta_{\mathrm{C}} 137.6$ (C-5). Based on these observations, the compound was concluded to be 4-(1,1-dimethylprop-2-enyl)1,3,5,8-tetrahydroxyxanthone (1, Fig. 1). The ${ }^{1} \mathrm{H}$ NMR, ${ }^{13} \mathrm{C}$ NMR and HMBC data for $\mathbf{1}$ are summarized in Table I.

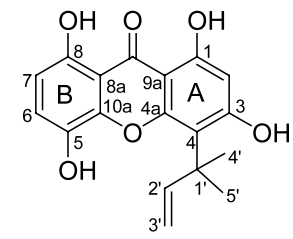

1

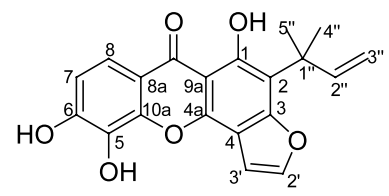

2<smiles>C=CC(C)(C)c1c2c(c3oc4c(O)c(O)ccc4c(=O)c3c1O)C=CC(C)(C)O2</smiles>

3<smiles>C=CC(C)(C)c1c(O)c(CC=C(C)C)c2oc3c(O)c(O)ccc3c(=O)c2c1O</smiles>

4<smiles>CC(C)=CCc1c2c(c(O)c3c(=O)c4ccc(O)c(O)c4oc13)C(C)(C)C(C)O2</smiles>
5
Fig. 1. Compounds isolated from $G$. penangiana leaves: 4-(1,1-dimethylprop-2-enyl)-1,3,5,8-tetrahydroxyxanthone (1), penangianaxanthone (2), cudratricusxanthone $\mathrm{H}$ (3), macluraxanthone C (4), and gerontoxanthone C (5).

Penangianaxanthone (2) was isolated as yellow fluffy crystals with a melting point of $216-218^{\circ} \mathrm{C}$. The HREI mass spectrum of this compound showed the molecular ion peak at $\mathrm{m} / z$ 352.0960,

\begin{tabular}{|c|c|c|c|}
\hline $\mathrm{C}$ & $\begin{array}{l}{ }^{13} \mathrm{C} \\
\text { chemical } \\
\text { shift }(\mathrm{ppm})\end{array}$ & $\begin{array}{l}{ }^{1} \mathrm{H} \text { chemical shift } \\
\text { (integration of proton, } \\
\text { multiplicity, } J \text { in } \mathrm{Hz} \text { ) }\end{array}$ & $\begin{array}{l}\text { HMBC correlations } \\
\text { (H to } \mathrm{C})\end{array}$ \\
\hline C-1 & 161.3 & $12.26(1 \mathrm{H}, \mathrm{s}, \mathrm{OH}-1)$ & $\mathrm{C}-1, \mathrm{C}-2, \mathrm{C}-9 \mathrm{a}$ \\
\hline $\mathrm{C}-2$ & 99.8 & $6.38(1 \mathrm{H}, \mathrm{s})$ & C-1, C-3, C-4, C-9a \\
\hline $\mathrm{C}-3$ & 165.5 & & \\
\hline C-4 & 112.5 & 155.0 & \\
\hline C-5 & 137.6 & & \\
\hline C-6 & 123.3 & $7.32(1 \mathrm{H}, \mathrm{d}, J=9.0)$ & C-8, C-5, C-10a \\
\hline $\mathrm{C}-7$ & 109.3 & $6.64(1 \mathrm{H}, \mathrm{d}, J=9.0)$ & C-8a, C-5 \\
\hline C-8 & 153.1 & $11.18(1 \mathrm{H}, \mathrm{s}, \mathrm{OH}-8)$ & C-7, C-8, C-8a \\
\hline $\mathrm{C}-8 \mathrm{a}$ & 107.4 & & \\
\hline C-9 & 185.2 & & \\
\hline C-9a & 102.2 & & \\
\hline C-10a & 144.0 & & \\
\hline $\mathrm{C}-1^{\prime}$ & 41.3 & & \\
\hline $\mathrm{C}-2^{\prime}$ & 151.6 & $6.58(1 \mathrm{H}, \mathrm{dd}, J=17.0,10.0)$ & $\mathrm{C}-4, \mathrm{C}-1^{\prime}, \mathrm{C}-2^{\prime}, \mathrm{C}-5^{\prime}$ \\
\hline C-3' & 107.4 & $\begin{array}{l}5.11(1 \mathrm{H}, \mathrm{dd}, J=17.0,1.5) \\
4.95(1 \mathrm{H}, \mathrm{dd}, J=10.0,1.5)\end{array}$ & $\begin{array}{l}\mathrm{C}-4, \mathrm{C}-1^{\prime}, \mathrm{C}-2^{\prime}, \mathrm{C}-4^{\prime} \\
\mathrm{C}-1^{\prime}, \mathrm{C}-4^{\prime}, \mathrm{C}-5^{\prime}\end{array}$ \\
\hline C-4' & 28.8 & $1.76(3 \mathrm{H}, \mathrm{s})$ & $\mathrm{C}-1^{\prime}, \mathrm{C}-2^{\prime}$ \\
\hline C-5' & 28.8 & $1.76(3 \mathrm{H}, \mathrm{s})$ & $\mathrm{C}-1^{\prime}$ \\
\hline
\end{tabular}

Table I. NMR spectroscopic data $\left({ }^{13} \mathrm{C}\right.$ at $125 \mathrm{MHz}$ and ${ }^{1} \mathrm{H}$ at $500 \mathrm{MHz}$, acetone- $d_{6}$ ) of compound $\mathbf{1}$. 
corresponding to the molecular formula $\mathrm{C}_{20} \mathrm{H}_{16} \mathrm{O}_{6}$. The UV spectral data is consistent with the xanthone chromophore with absorption maxima at 258, 280, 326 and $381 \mathrm{~nm}$. The IR spectrum showed the presence of carbonyl and $\mathrm{OH}$ functionalities by absorption bands at 1582 and $3427 \mathrm{~cm}^{-1}$, respectively.

In the ${ }^{1} \mathrm{H}$ NMR spectrum, the presence of a 1,1dimethylallyl group was noted by the presence of proton signals at $\delta_{\mathrm{H}} 6.48(\mathrm{dd}, J=17.0,10.0 \mathrm{~Hz}, \mathrm{H}-$ $\left.2^{\prime \prime}\right), \delta_{\mathrm{H}} 5.03\left(\mathrm{~d}, 17.0 \mathrm{~Hz}, \mathrm{H}_{\text {trans }}-3^{\prime \prime}\right), \delta_{\mathrm{H}} 4.95(\mathrm{~d}, J=$ $\left.10.0 \mathrm{~Hz}, \mathrm{H}_{c i s}-3^{\prime \prime}\right)$ and two overlapping methyl peaks at $\delta_{\mathrm{H}} 1.77$. In the ${ }^{1} \mathrm{H}^{-1} \mathrm{H}$ COSY experiment (Table II) the proton signal at $\delta_{\mathrm{H}} 6.48\left(\mathrm{H}-2^{\prime \prime}\right)$ was correlated with proton signals at $\delta_{\mathrm{H}} 5.03\left(\mathrm{H}-3^{\prime \prime}{ }_{\text {trans }}\right)$ and $\delta_{\mathrm{H}} 4.95\left(\mathrm{H}-3^{\prime \prime}{ }_{c i s}\right)$, which further supported the presence of an allylic system. The HSQC spectrum showed the correlation between the allylic methine proton signal at $\delta_{\mathrm{H}} 6.48$ with the carbon signal at $\delta_{\mathrm{C}} 148.1\left(\mathrm{C}-2^{\prime \prime}\right)$, while terminal allylic methylene proton signals at $\delta_{\mathrm{H}} 5.03$ and $\delta_{\mathrm{H}} 4.95$ correlated with a carbon signal at $\delta_{\mathrm{C}} 109.1\left(\mathrm{C}-3^{\prime \prime}\right)$. The HMBC spectrum further showed the correlation of a dimethyl proton signal at $\delta_{\mathrm{H}} 1.77\left(\mathrm{H}-4^{\prime \prime}\right.$ and $\left.\mathrm{H}-5^{\prime \prime}\right)$ with the allylic carbon atom $\left(\delta_{\mathrm{C}} 148.1\right.$, C-2"). Correlation of dimethyl allyl proton signals at $\delta_{\mathrm{H}} 1.77\left(\mathrm{CH}_{3}-4^{\prime \prime}\right.$ and $\left.\mathrm{CH}_{3}-5^{\prime \prime}\right)$ with the carbon signal at $\delta_{\mathrm{C}} 113.5(\mathrm{C}-2)$ suggested the connectivity of the 1,1-dimethylallyl moiety to the xanthone skeleton through $\mathrm{C}-2$. In the ${ }^{1} \mathrm{H}$ NMR low field region, a chelated hydroxy proton signal at $\delta_{\mathrm{H}}$ $13.94(\mathrm{OH}-1)$, which correlated with the carbon signals at $\delta_{\mathrm{C}} 158.3(\mathrm{C}-1), \delta_{\mathrm{C}} 113.5(\mathrm{C}-2)$ and $\delta_{\mathrm{C}}$ 104.9 (C-9a), was observed in the HMBC spectrum, thus confirming the position of the chelated hydroxy group at C-1.

The presence of two methine protons in the fused furan ring was noted from the ${ }^{1} \mathrm{H}$ NMR spectrum by the signals at $\delta_{\mathrm{H}} 7.38(\mathrm{~d}, J=2.0 \mathrm{~Hz}$, H-3 $\left.{ }^{\prime}\right)$ and $\delta_{\mathrm{H}} 7.86\left(\mathrm{~d}, J=2.0 \mathrm{~Hz}, \mathrm{H}-2^{\prime}\right)$, which mutually correlated in the ${ }^{1} \mathrm{H}-{ }^{1} \mathrm{H}$ COSY spectrum. The HSQC spectrum further allowed the assignment of the furanyl carbon signals at $\delta_{\mathrm{C}} 103.9$ and $\delta_{\mathrm{C}} 144.1$ to $\mathrm{C}-3^{\prime}$ and $\mathrm{C}-2^{\prime}$, respectively. The connectivity of the fused furan ring to the xanthone skeleton was further determined by the HMBC spectrum. The correlations between $\mathrm{H}-3^{\prime}\left(\delta_{\mathrm{H}} 7.38\right)$ with the carbon signals at $\delta_{\mathrm{C}} 148.7(\mathrm{C}-4 \mathrm{a}), \delta_{\mathrm{C}} 158.7$ $(\mathrm{C}-3)$ and $\delta_{\mathrm{C}} 144.1\left(\mathrm{C}-2^{\prime}\right)$ and the other methine proton, $\mathrm{H}-2^{\prime}\left(\delta_{\mathrm{H}} 7.86\right)$, with the carbon signals at $\delta_{\mathrm{C}} 158.7(\mathrm{C}-3), \delta_{\mathrm{C}} 109.3(\mathrm{C}-4)$ and $\delta_{\mathrm{C}} 103.9\left(\mathrm{C}-3^{\prime}\right)$ suggested that the connection of the fused furan ring was at C-4 and C-3 of the xanthone skeleton.

In the ${ }^{1} \mathrm{H}$ NMR spectrum, two ortho-coupled aromatic proton signals $\left(\mathrm{AB}\right.$ system) at $\delta_{\mathrm{H}} 7.77(\mathrm{~d}$, $J=8.5 \mathrm{~Hz})$ and $\delta_{\mathrm{H}} 7.09(\mathrm{~d}, J=8.5 \mathrm{~Hz})$ were observed. The former was assigned to $\mathrm{H}-8$ due to its $\mathrm{HMBC}$ correlation with the carbon signals at $\delta_{\mathrm{C}}$

Table II. NMR spectroscopic data $\left({ }^{13} \mathrm{C}\right.$ at $125 \mathrm{MHz}$ and ${ }^{1} \mathrm{H}$ at $500 \mathrm{MHz}$, acetone- $\left.d_{6}\right)$ of compound 2.

\begin{tabular}{|c|c|c|c|c|}
\hline $\mathrm{C}$ & $\begin{array}{l}{ }^{13} \mathrm{C} \text { chemical } \\
\text { shift }(\mathrm{ppm})\end{array}$ & $\begin{array}{l}{ }^{1} \mathrm{H} \text { chemical shifts (integration } \\
\text { of proton, multiplicity, } J \text { in } \mathrm{Hz} \text { ) }\end{array}$ & COSY & HMBC correlations ( $\mathrm{H}$ to $\mathrm{C})$ \\
\hline $\mathrm{C}-1$ & 158.3 & \multirow[t]{7}{*}{$13.94(1 \mathrm{H}, \mathrm{s}, \mathrm{OH}-1)$} & & \multirow[t]{7}{*}{ C-1, C-2, C-9a } \\
\hline $\mathrm{C}-2$ & 113.5 & & & \\
\hline $\mathrm{C}-3$ & 158.7 & & & \\
\hline $\mathrm{C}-4$ & 109.3 & & & \\
\hline $\mathrm{C} 4 \mathrm{a}$ & 148.7 & & & \\
\hline C-5 & 132.6 & & & \\
\hline C-6 & 146.0 & & & \\
\hline $\mathrm{C}-7$ & 113.7 & $7.09(1 \mathrm{H}, \mathrm{d}, J=8.5)$ & $\mathrm{H}-8$ & C-8a, C-5 \\
\hline C-8 & 117.1 & \multirow[t]{6}{*}{$7.77(1 \mathrm{H}, \mathrm{d}, J=8.5)$} & \multirow[t]{6}{*}{$\mathrm{H}-7$} & \multirow[t]{6}{*}{ C-9, C-6, C-10a, C-8a } \\
\hline $\mathrm{C}-8 \mathrm{a}$ & 114.4 & & & \\
\hline C-9 & 182.0 & & & \\
\hline C-9a & 104.9 & & & \\
\hline & 152.0 & & & \\
\hline C-1" & 40.9 & & & \\
\hline $\mathrm{C}-2^{\prime \prime}$ & 148.1 & $6.48(1 \mathrm{H}, \mathrm{dd}, J=17.0,10.0)$ & $\mathrm{H}-3^{\prime \prime}{ }_{\text {cis }}, \mathrm{H}-3^{\prime \prime}{ }_{\text {trans }}$ & C-2, C-1", C-4", C-5" \\
\hline \multirow[t]{2}{*}{ C-3" } & 109.1 & $5.03(1 \mathrm{H}, \mathrm{d}, J=17.0)$ & $\mathrm{H}-2^{\prime \prime}$ & $\mathrm{C}-2^{\prime \prime}, \mathrm{C}-1^{\prime \prime}$ \\
\hline & & $4.95(1 \mathrm{H}, \mathrm{d}, J=10.0)$ & $\mathrm{H}-2^{\prime \prime}$ & C-1" \\
\hline $\mathrm{C}-4^{\prime \prime}$ & 28.1 & $1.77(3 \mathrm{H}, \mathrm{s})$ & & C-2, C-2", C-1", C-4", C-5" \\
\hline$C-5^{\prime \prime}$ & 28.1 & $1.77(3 \mathrm{H}, \mathrm{s})$ & & C-2, C-2", C-1", C-4", C-5" \\
\hline $\mathrm{C}-2^{\prime}$ & 144.1 & $7.86(1 \mathrm{H}, \mathrm{d}, J=2.0)$ & $3^{\prime}$ & $\mathrm{C}-3^{\prime}, \mathrm{C}-4, \mathrm{C}-3$ \\
\hline C-3' & 103.9 & $7.38(1 \mathrm{H}, \mathrm{d}, J=2.0)$ & $2^{\prime}$ & C-4a, C-3, C-2' \\
\hline
\end{tabular}


$182.0(\mathrm{C}-9), \delta_{\mathrm{C}} 146.0(\mathrm{C}-6)$ and $\delta_{\mathrm{C}} 152.0(\mathrm{C}-10 \mathrm{a})$, while the latter was assigned to $\mathrm{H}-7$ due to its HMBC correlation signals at $\delta_{\mathrm{C}} 114.4(\mathrm{C}-8 \mathrm{a})$ and $\delta_{\mathrm{C}} 132.6(\mathrm{C}-5)$. Comparison of respective data for proton and carbon signals in previously isolated xanthone compounds, containing a fused furanyl system in subelliptenone C and D (Iinuma et al., 1995, 1996), supported the assignments. Based on these observations (see Table II), compound 2 was assigned as penangianaxanthone or 1,5,6-trihydroxy-2-( $\left(1^{\prime}, 1^{\prime}\right.$-dimethylallyl)furano $\left(4^{\prime}, 5^{\prime}: 3,4\right)$ xanthone (Fig. 1).

From the biogenetic point of view, compounds $\mathbf{2}, \mathbf{3}$ and 5 may have the common origin of compound 4. Intramolecular cyclization of $3-\mathrm{OH}$ with the 2-prenyl moiety led to compound $\mathbf{5}$, while cyclization of 3-OH with an epoxidized 4-prenyl moiety led to pyranoxanthone $\mathbf{3}$ or a furanoxanthone intermediate which underwent further elimination of the isopropyl moiety to penangianaxanthone (2).

The cytotoxic activity test of the isolates against three cell lines, MCF-7 (hormone-dependent breast cancer), NCI-H460 (non-small lung cancer) and DU-145 (non-hormone-dependent prostate cancer), was conducted and the results are presented in Table III. All compounds except for friedelin and stigmasterol showed strong to weak activity towards MCF-7 cell lines. Xanthones 2-5 showed strong cytotoxic activity towards MCF-7, NCI-H460 and DU-145 cell lines, with $\mathrm{IC}_{50}$ values ranging between 3.5 to $16.4 \mu \mathrm{M}$, while $\mathbf{1}$ showed only weak activity towards MCF-7 and NCI-H460, with $\mathrm{IC}_{50}$ values of $72.8 \mu \mathrm{M}$ and $40.8 \mu \mathrm{M}$, respec-

Table III. Cytotoxic activity of compounds isolated from G. penangiana.

\begin{tabular}{lrrr}
\hline Compound & \multicolumn{3}{c}{$\mathrm{IC}_{50}[\mu \mathrm{M}]^{\mathrm{a}}$} \\
\cline { 2 - 4 } & $\mathrm{MCF}-7$ & $\mathrm{NCI}-\mathrm{H} 460$ & $\mathrm{DU}-145$ \\
\hline $\mathbf{1}$ & $72.8 \pm 2.6$ & $40.8 \pm 1.1$ & nd \\
$\mathbf{2}$ & $16.4 \pm 1.2$ & $12.7 \pm 1.4$ & $12.2 \pm 0.4$ \\
$\mathbf{3}$ & $9.8 \pm 0.8$ & $12.6 \pm 1.2$ & $11.7 \pm 0.2$ \\
$\mathbf{4}$ & $7.8 \pm 0.1$ & $3.5 \pm 0.9$ & $6.6 \pm 0.6$ \\
$\mathbf{5}$ & $7.6 \pm 0.2$ & $5.0 \pm 0.7$ & $7.6 \pm 0.4$ \\
Friedelin & na & nd & nd \\
Stigmasterol & na & nd & nd \\
\hline
\end{tabular}

\footnotetext{
a Results are expressed as $\mathrm{IC}_{50}$ values $\pm \mathrm{SD}$ of three experiments performed in four replicates; MCF-7, human breast cancer $(\mathrm{Re}+)$; NCI-H460, non-small human lung cancer; DU-145, human prostate cancer; na, not active; nd, not determined.
}

tively. Compound 4 seemed to be the most cytotoxic among the isolates.

The most obvious structural difference between compounds $\mathbf{1}$ and $\mathbf{2}-\mathbf{5}$ is the location of two hydroxy groups in ring $\mathrm{B}$. While compound $\mathbf{1}$ has two hydroxy groups located para to each other (C-5 and $\mathrm{C}-8$ ), the hydroxy groups in compounds $\mathbf{2}-\mathbf{5}$ are located ortho (C-5 and C-6) to each other. This factor may therefore be responsible for the cytotoxic activity of these compounds. The presence of ortho-dihydroxy groups in the aromatic system of antioxidative compounds such as curcuminoids, cinnamonoids and feruloids has been emphasized in previous reports (Cai et al., 2006; Kanski et al., 2002; Mansouri et al., 2005; Notarbartolo et al., 2005; Sen et al., 2005). The principle of antioxidative compounds in expressing cytotoxic activity has also been proposed for example in the case of curcumin (Notarbartolo et al., 2005; Sen et al., 2005). The presence of one or two prenyl moieties in ring A, either cyclized into furanyl or pyranyl rings, did not seem to affect the cytotoxic activity.

\section{Experimental}

\section{General experimental procedures}

NMR spectra were recorded on a Varian Unity 500 spectrometer using $\mathrm{CD}_{3} \mathrm{OD}, \mathrm{CDCl}_{3}$ and acetone- $d_{6}$ as solvents. Chemical shifts are recorded in $\delta(\mathrm{ppm})$ with tetramethylsilane (TMS) as an internal reference. All mass spectra were taken under EI condition, using a PolarisQ mass spectrometer and a Finnigan MAT95XL-T HREIMS instrument. UV spectra were recorded on a CARY Conc 100 spectrometer in $\mathrm{MeOH}$ and IR spectra on an FTIR Perkin Elmer spectrometer 1650 in $\mathrm{KBr}$ disc.

\section{Plant material}

The plant material was collected from the Fraser Hill Forest Reserve (elevation: $1100 \mathrm{~m}$ above the sea level) in Pahang, Malaysia, and was classified by Mr. Shamsul Khamis, a resident botanist of the Institute of Bioscience, University Putra Malaysia. The sample (SK 95/01) was deposited in the herbarium of the Institute of Bioscience, University $\mathrm{Pu}$ tra Malaysia.

\section{Extraction}

The air-dried $(1.5 \mathrm{~kg})$ leaves of $G$. penangiana were ground to powder and soaked in methanol 
$(\mathrm{MeOH})$ for $2 \mathrm{~d}$ at room temperature and the extract was filtered. The solvent was removed under reduced pressure. The extraction was repeated for 3 times and the combined $\mathrm{MeOH}$ extract $(77 \mathrm{~g})$ was partitioned into hexane, DCM, EA and butanol to yield $4.2 \mathrm{~g}, 12.3 \mathrm{~g}, 5.2 \mathrm{~g}$ and $35.9 \mathrm{~g}$, respectively, of the dried fractionated extracts.

\section{Isolation of compounds 1, 2, 3, 4 and 5}

Approx. $4.2 \mathrm{~g}$ of the hexane-fractionated extract was subjected to gel permeation chromatography (Sephadex LH-20, $2.5 \mathrm{~cm} \phi \times 40 \mathrm{~cm}$ ) with methanol/chloroform (1:1) as an eluant, to give eight $(20 \mathrm{ml})$ fractions. Fractions $1-3$ were combined and further purified to yield $10 \mathrm{mg}$ of friedelin and $2 \mathrm{mg}$ of stigmasterol. The combined fractions 4-8 $(1.8 \mathrm{~g})$ were subjected to silica gel column chromatography $(2 \mathrm{~cm} \phi \times 40 \mathrm{~cm})$ and eluted with hexane/EA/MeOH mixtures, in ascending polarity manner, to give $30(10 \mathrm{ml})$ fractions. The fractions were combined into 4 fractions based on their TLC profile. Fraction $3(96.9 \mathrm{mg})$ was subjected to further silica gel column chromatography $(1 \mathrm{~cm}$ $\phi \times 30 \mathrm{~cm})$ eluting with hexane/EA $(8: 2)$ to yield $4 \mathrm{mg}$ of $\mathbf{1}$. Fraction $4(41.5 \mathrm{mg})$ was subjected onto a C-18 reverse phase silica column and eluted with $\mathrm{MeOH} /$ water mixtures to give $\mathbf{3}(8.3 \mathrm{mg})$.

The DCM fraction $(12.3 \mathrm{~g})$ was subjected to a silica gel column $(10 \mathrm{~cm} \phi \times 30 \mathrm{~cm})$ and eluted in ascending polarity manner with hexane/DCM/EA/ $\mathrm{MeOH}$ mixtures to give 9 combined fractions (AI) based on their TLC pattern. Fraction E (6.8 g) was subjected to gel permeation column chromatography (Sephadex LH-20, $2.5 \mathrm{~cm} \phi \times 30 \mathrm{~cm}$ ) with a methanol/chloroform (1:1) mixture as eluant to give fifteen $(20 \mathrm{ml})$ fractions. The combined fractions $9-15(408 \mathrm{mg})$ were subjected to C-18 reverse phase column chromatography $(2.5 \mathrm{~cm}$ $\phi \times 30 \mathrm{~cm}$ ) using $\mathrm{MeOH} /$ water as eluant to afford $20.4 \mathrm{mg}$ of compound 2 . The combined fractions 4-8 (4 g) were subjected to reverse phase column chromatography $(4.0 \mathrm{~cm} \phi \times 30 \mathrm{~cm})$ and eluted with a $\mathrm{MeOH} /$ water mixture in descending manner to afford compounds $\mathbf{2}(40 \mathrm{mg})$ and $\mathbf{5}(80 \mathrm{mg})$. Fraction D ( $1.7 \mathrm{~g})$ was also subjected to C-18 reverse phase column chromatography $(2 \mathrm{~cm}$ $\phi \times 30 \mathrm{~cm})$ and eluted with $\mathrm{MeOH} /$ water to afford $67.7 \mathrm{mg}$ of the yellow amorphous solid of compound 4 .

4-(1,1-Dimethylprop-2-enyl)-1,3,5,8-tetrahydroxyxanthone (1): Yellow amorphous solid, m.p. 220- $222^{\circ} \mathrm{C} .-\mathrm{IR}(\mathrm{KBr}): v_{\max }=3392(\mathrm{OH}$ stretching $)$, 2922 ( $\mathrm{CH}$ stretching), 2848 ( $\mathrm{sp}^{3} \mathrm{CH}$ stretching), 1585 (carbonyl stretching), $1031 \mathrm{~cm}^{-1}$ (out of plane bending of alkene). - UV (MeOH): $\lambda_{\max }$ $(\log \varepsilon)=226$ (3.88), 256 (3.94), 281 (3.76), $325 \mathrm{~nm}$ (3.59). - HREIMS: $\mathrm{m} / z=328.3269$ (calcd. for $\left.\mathrm{C}_{18} \mathrm{H}_{16} \mathrm{O}_{6}: 328.3246\right) .-$ MS: $m / z=328\left[\mathrm{M}^{+}\right](32)$, 313 [ $\mathrm{M}^{+}$-methyl] (100), 285 (46), 273 (26), 257 (38), 244 (18), 149 (24), 129 (22), 105 (18), 91 (36), 83 (68), 76 (28), 56 (24), 46 (34), 44 (79). - ${ }^{1} \mathrm{H}$ NMR (acetone- $d_{6}, 500 \mathrm{MHz}$ ) and ${ }^{13} \mathrm{C}$ NMR (acetone- $d_{6}$, $125 \mathrm{MHz}$ ): see Table I.

Penangianaxanthone (2): Yellow fluffy crystals, m.p. $216-218^{\circ} \mathrm{C}$. - IR $(\mathrm{KBr}): v_{\max }=3427(\mathrm{OH}$ stretching), 2900 (CH stretching), $2830 \quad(\mathrm{CH}$ stretching), 1582 (carbonyl stretching), 1414, 1332, $1314,1284,1239,1215,1174,1132,1095 \mathrm{~cm}^{-1}$. UV (MeOH): $\lambda_{\max }(\log \varepsilon)=258$ (4.25), 280 (4.05), 326 (3.82), 381 (3.55). - HREIMS: $m / z=352.0960$ (calcd. for $\mathrm{C}_{20} \mathrm{H}_{16} \mathrm{O}_{6}: 352.0946$ ). - MS: $m / z=352$ $\left[\mathrm{M}^{+}\right]$(42), 336 [352-methyl-H] (100), 318 [336$\left.\mathrm{H}_{2} \mathrm{O}\right]$ (56), 297 (90), 280 (26), 253 (6), 189 (6), 153 (6), 147 (10), 97 (16), 81 (22), 57 (24). - ${ }^{1} \mathrm{H}$ NMR (acetone- $d_{6}, 500 \mathrm{MHz}$ ) and ${ }^{13} \mathrm{C}$ NMR (acetone- $d_{6}$, $125 \mathrm{MHz}$ ): see Table II.

Cudratricusxanthone $H$ (3): Yellow needles, m.p. 174-176 ${ }^{\circ} \mathrm{C}$ (lit. m.p. $175^{\circ} \mathrm{C}$ (Kanski et al., 2002)]. - MS, ${ }^{1} \mathrm{H}$ NMR, ${ }^{13} \mathrm{C}$ NMR data are consistent with cudratricusxanthone $\mathrm{H}$ (Zou et al., 2004).

Macluraxanthone $C(4)$ : Yellow amorphous solid, m.p. $204{ }^{\circ} \mathrm{C}$ (lit. m.p. is not available). - MS, ${ }^{1} \mathrm{H}$ NMR, ${ }^{13} \mathrm{C}$ NMR data are consistent with macluraxanthone C (Groweiss and Boyd, 2000).

Gerontoxanthone $C$ (5): Yellow amorphous solid, m.p. $205-207^{\circ} \mathrm{C}$ (lit. m.p. $204-206^{\circ} \mathrm{C}$ ). - MS, ${ }^{1} \mathrm{H}$ NMR, ${ }^{13} \mathrm{C}$ NMR data are consistent with gerontoxanthone C (Chang et al., 1989).

Friedelin: White needles, m.p. $\quad 260-262{ }^{\circ} \mathrm{C}$ (lit. m.p. $262-265^{\circ} \mathrm{C}$ ). - MS, ${ }^{1} \mathrm{H}$ NMR, ${ }^{13} \mathrm{C}$ NMR data are consistent with friedelin (Queiroga et al., 2000).

Stigmasterol: White needles, m.p. $168-170{ }^{\circ} \mathrm{C}$ (lit. m.p. $170{ }^{\circ} \mathrm{C}$ ) (Forgo and Kover, 2004). 


\section{In vitro test for cytotoxic activity (MTT assay)}

Three types of human tumour cell lines, DU145, MCF-7 and NCI-H460, were used in the cytotoxicity study. Crude extracts or compounds were tested at $0.1 \mu \mathrm{g} / \mathrm{ml}, 1 \mu \mathrm{g} / \mathrm{ml}, 10 \mu \mathrm{g} / \mathrm{ml}$ and $100 \mu \mathrm{g} /$ $\mathrm{ml}$ concentrations and each concentration was performed in 4 replicates. The assay was conducted according to the previously described protocol (Stanslas et al., 2000 ).

Ali S., Goundar R., Sotheeswaran S., Beaulieu C., and Spino C. (2000), Benzophenones of Garcinia pseudoguttifera (Clusiaceae). Phytochemistry 53, 281-284.

Burkill I. H. (1966), A Dictionary of the Economics Products of the Malay Peninsula. Ministry of Agriculture and Cooperation, Kuala Lumpur, Malaysia.

Cai Y.-Z., Mei S., Jie X., Luo Q., and Corke H. (2006), Structure-radical scavenging activity relationships of phenolic compounds from traditional Chinese medicinal plants. Life Sci. 78, 2872-2888.

Cao S. G., Wu X. H., Sim K. Y., Tan B. K. H., Pereira J. T., Wong W. H., Hew N. F., and Goh S. H. (1998), Cytotoxic caged tetraprenylated xanthonoids from Garcinia gaudichaudii (Guttiferae). Tetrahedron Lett. 39, 3353-3356.

Chang C.-H., Lin C.-C., Hattori M., and Namba T. (1989), Four prenylated xanthones from Cudrania cochinchinensis. Phytochemistry 28, 595-598.

Chiang Y. M., Kuo Y. H., Oota S., and Fukuyama Y. (2003), Xanthones and benzophenones from the stems of Garcinia multiflora. J. Nat. Prod. 66, 10701073.

Chomnawang M. T., Surassmo S., Nukoolkarn V. S., and Gritsanapan W. (2005), Antimicrobial effects of Thai medicinal plants against acne-inducing bacteria. J. Ethnopharmacol. 101, 330-333.

Forgo P. and Kover K. E. (2004), Gradient enhanced selective experiments in the ${ }^{1} \mathrm{H}$ NMR chemical shift assignment of the skeleton and side-chain resonances of stigmasterol, a phytosterol derivative. Steroids 69, $43-50$.

Govindachari T. R., Kalyanaraman P. S., Muthukumaraswamy N., and Pai B. R. (1971), Xanthones of Garcinia mangostana Linn. Tetrahedron 27, 3919-3926.

Grosvenor P. W., Gothard P. K., McWilliam N. C., Supriono A., and Gray D. O. (1995), Medicinal plants from Riau Province, Sumatra, Indonesia. Part 1: Uses. J. Ethnopharmacol. 45, 75-95.

Groweiss A. and Boyd M. R. (2000), HIV-inhibitory prenylated xanthones and flavones from Maclura tinctoria. J. Nat. Prod. 63, 1537-1539.

Iinuma M., Hedeki T., Toshiyuki T., Fujio A., and Ryoyu S. (1995), Two new xanthones from the root bark of Garcinia subelliptica. Heterocycles 40, 279-284.

\section{Acknowledgement}

The authors are grateful to the Ministry of Science, Technology and the Environment, Malaysia for its financial support and the IRPA-EAR research grant No. 09-02-04-0313. M. L. J. is grateful to the Malaysian Agriculture Research and Development Institute (MARDI) for the scholarship provided to complete his Master of Science Programme.
Iinuma M., Ito T., Tosa H., Tanaka T., and Riswan S. (1996), Five new xanthones from Garcinia dulcis. J. Nat. Prod. 59, 472-475.

Ito C., Itoigawa M., Takakura T., Ruangrungsi N., Enjo F., Tokuda H., Nishino H., and Furukawa H. (2003), Chemical constituents of Garcinia fusca: Structure elucidation of eight new xanthones and their cancer chemopreventive activity. J. Nat. Prod. 66, 200-205.

Kanski J., Aksenova M., Stoyanova A., and Butterfield D. A. (2002), Ferulic acid antioxidant protection against hydroxyl and peroxyl radical oxidation in synaptosomal and neuronal cell culture systems in vitro: structure-activity studies. J. Nut. Biochem. 13, 273281.

Lin Y. M., Anderson H., Flavin M. T., Pai Y. H. S., MataGreenwood E., Pengsuparp T., Pezzuto J. M., Schinazi R. F., Hughes S. H., and Chen F. C. (1997), In vitro anti-HIV activity of biflavonoids isolated from Rhus succedanea and Garcinia multiflora. J. Nat. Prod. 60, $884-888$.

Mackeen M. M., Ali A. M., Lajis N. H., Kawazu K., Hassan Z., Amran M., Habsah M., Mooi L. Y., and Mohamed S. M. (2000), Antimicrobial, antioxidant, antitumour-promoting and cytotoxic activities of different plant part extracts of Garcinia atroviridis Griff. ex T. Anders. J. Ethnopharmacol. 72, 395-402.

Mansouri A., Makris D. P., and Kefalas P. (2005), Determination of hydrogen peroxide scavenging activity of cinnamic and benzoic acids employing a highly sensitive peroxyoxalate chemiluminescence-based assay: Structure-activity relationships. J. Pharm. Biomed. Anal. 39, 22-26.

Matsumoto K., Akao Y., Kobayashi E., Ito T., Ohguchi K., Tanaka T., Iinuma M., and Nozawa Y. (2003a), Cytotoxic benzophenone derivatives from Garcinia species display a strong apoptosis-inducing effect against human leukemia cell lines. Biol. Pharm. Bull. 26, 569-571.

Matsumoto K., Akao Y., Kobayashi E., Ohguchi K., Ito T., Tanaka T., Iinuma M., and Nozawa Y. (2003b), Induction of apoptosis by xanthones from mangosteen in human leukemia cell lines. J. Nat. Prod. 66, 11241127.

Nakatani K., Nakahata N., Arakawa T., Yasuda H., and Ohizumi Y. (2002), Inhibition of cyclooxygenase and 
prostaglandin E2 synthesis by $\alpha$-mangostin, a xanthone derivative in mangosteen, in C6 rat glioma cells. Biochem. Pharmacol. 63, 73-79.

Notarbartolo M., Poma P., Perri D., Dusonchet L., Cervello M., and D'Alessandro N. (2005), Antitumor effects of curcumin, alone or in combination with cisplatin or doxorubicin, on human hepatic cancer cells. Analysis of their possible relationship to changes in $\mathrm{NF}-\alpha \mathrm{B}$ activation levels and in IAP gene expression. Cancer Lett. 224, 53-65.

Peres V., Nagem T. J., and de Oliveira F. F. (2000), Tetraoxygenated naturally occurring xanthones. Phytochemistry $\mathbf{5 5}, 683-710$.

Permana D., Lajis N. H., Mackeen M. M., Ali A. M., Aimi N., Kitajima M., and Takayama H. (2001), Isolation and bioactivities of constitutents of the roots of Garcinia atroviridis. J. Nat. Prod. 64, 976-979.

Queiroga C. L., Silva G. F., Dias P. C., Possenti A., and de Carvalho J. E. (2000), Evaluation of the antiulcerogenic activity of friedelan-3[beta]-ol and friedelin isolated from Maytenus ilicifolia (Celastraceae). J. Ethnopharmacol. 72, 465-468.

Rukachaisirikul V., Kamkaew M., Sukavisit D., Phongpaichit S., Sawangchote P., and Taylor W. C. (2003), Antibacterial xanthones from the leaves of Garcinia nigrolineata. J. Nat. Prod. 66, 1531-1535.
Sen S., Sharma H., and Singh N. (2005), Curcumin enhances vinorelbine mediated apoptosis in NSCLC cells by the mitochondrial pathway. Biochem. Biophys. Res. Commun. 331, 1245-1252.

Stanslas J., Hagan D. J., Ellis M. J., Turner C., Carmichael J., Ward W., Hammonds T. R., and Stevens M. F. G. (2000), Antitumor polycyclic acridines. 7. Synthesis and biological properties of DNA affinic tetra- and pentacyclic acridines. J. Med. Chem. 43, $1563-1572$.

Thoison O., Fahy J., Dumontet V., Chiaroni A., Riche C., Van Tri M., and Sevenet T. (2000), Cytotoxic prenylxanthones from Garcinia bracteata. J. Nat. Prod. 63, $441-446$.

Tona L., Ngimbi N. P., Tsakala M., Mesia K., Cimanga K., Apers S., De Bruyne T., Pieters L., Totte J., and Vlietinck A. J. (1999), Antimalarial activity of 20 crude extracts from nine African medicinal plants used in Kinshasa, Congo. J. Ethnopharmacol. 68, 193-203.

Waterman P. G. and Hussain R. A. (1983), Systematic significance of xanthones, benzophenones and biflavonoids in Garcinia. Biochem. Syst. Ecol. 11, 21-28.

Zou Y.-S., Hou A.-J., Zhu G.-F., Chen Y.-F., Sun H.-D., and Zhao Q.-S. (2004), Cytotoxic isoprenylated xanthones from Cudrania tricuspidata. Bioorg. Med. Chem. 12, 1947-1953. 